\begin{tabular}{|l|l|}
\hline Article No: AREA12198 & Delivery date: 13 Apr 2015 \\
\hline Page Extent: 8 & \\
\hline
\end{tabular}

Area, 2015, doi: 10.1111/area.12198

\title{
Visualising the visceral: using film to research the ineffable
}

\author{
Jessica Jacobs \\ School of Geography, Queen Mary, University of London, London E1 4NS \\ Email: j.jacobs@qmul.ac.uk
}

Revised manuscript received 12 March 2015

\begin{abstract}
While cheaper technology, wider training availability and the online digital learning environment have broadened the opportunities for geographers to use film and video, it has also led to calls to improve the discipline's media literacy. This need is made even more urgent by the shift in qualitative research to practice-based methods targeted towards how we experience our lived environment. Other shifts in empirical and conceptual focus are also relevant, particularly interest in emotional beneath the surface geographies and calls for participation rather than observation encased in recent debates on the Anthropocene. The negative association of film with entertainment and marketeering has led to concerns about the suitability of film as a research output and has led some scholars to restrict themselves to a stringent use of real-time 'video' in a primarily data-collection context. This paper adopts a practicebased approach in order to identify some of the complex qualities that a research film holds and contribute to the debate about its future as a form of academic research and publication. Reflecting on a recent film-based research project on heritage tourism in Syria and Jordan I argue that the potential to manipulate, distort or entertain should not be ignored or refuted. Rather the wide range of relationships between people, objects and landscape within the frame such as depth of field, mise-en-scene and between the frames via editing (montage) give film a complex viscerality and multi-sensorial power that can help us explore how we communicate our feelings and connect the experiential qualities of filmic research methods to final outputs.
\end{abstract}

Key words: visual methods, qualitative research, geographies of film, emotional geographies, heritage tourism, digital media

\section{Introduction}

Film and video media are pivotal to the representation, communication and interpretation of geographical knowledge. Cinematic (particularly in relation to landscape) analysis is a relatively well-established field. The 'cultural turn' of the 1980s acknowledged the discipline's dependency on the visual (in Cosgrove and Daniel's 1988 3 phrase it was thought of as the 'eye' of history) and opened the way for a rigorous exploration of the relationship between geography and film (e.g. Cresswell and Dixon 2002; Lukinbeal and Zimmermann 2006). The use of digital video has also become an increasingly popular tool, particularly real-time video in a data-collection context (Haw and Hadfield 2011; Pauwels 2010). Documentary films and video clips in PowerPoint presentations are also well-established tools for geographical teaching and dissemination.

However, as Rose has pointed out, while geography might well depend on 'visualities and visual images to construct its knowledges' $(2001,212)$, it does not always consider the consequences of this dependency. More recently and in more practical terms, Lukinbeal has noted that 'while geographers increasingly use media to teach, students often are not taught how to critically evaluate what are media and how they produce geographic meaning' (2014, 41). This means that 'underlying literacies that link geography to media remain uncharted'.

If geographers are to pay more attention to the practices that make representations, one of the best ways is through the process and practice of making films. Cheaper and easier access to the necessary tools, skills and equipment 
JOBNAME: No Job Name PAGE: 2 SESS: 10 OUTPUT: Mon Apr 13 14:10:59 2015

/Xpp84_Wiley/wiley_journal_A/AREA/area_v0_i0/area_12198

required to make films as well as the ongoing digitisation of the learning environment means that more and more geographers are not just writing about films, but making them. The use of film and video as both a research tool and a form of dissemination is an exciting new and growing field, particularly in the realm of the film as essay

9 (Kieller 2010; see also Massey 2011), documentary

10 (Collard 2014; Gandy 2007), ethnomethodology (Laurier [1112 2010), research reports (Baptiste 2014), participatory video (Kindon et al. 2007; Parr 2007), digital storytelling

[13 (Bliss 2011) and videography (Garrett 2011; Merchant 2011).

While the current surge of interest in the use of digital video is very welcome (and long overdue), many questions remain. Rather than mimic existing film formats used in the film and television industry or adopted by other disciplines, the need for greater media literacy begins with investigating further how film is constructed and what constitutes a geographical film. Moreover, we need a better understanding of how film differs from other research methods and what particular qualities of film make it useful for which kind of research. Related to this is the question about the use of film as a form of publication, in particular the urgent issue of how we can begin to incorporate film more fully into the peer-review process. The gaps in our filmic literacy and the current lack of opportunity for filmic publication highlight the urgency for a greater understanding in the discipline of how digital media in general works, from its production to its consumption, both at the time it is made and screened and later, when it transfers to the archive.

Rather than getting too stuck on the premise that film is a 'visual research method' - a canon of work still primar- ily concerned with still images (Rose 2012) - this paper 14 wishes to begin to address the above questions from the stance that the multi-sensorial and mutable (Mariategui 2011) qualities of film take it beyond the visual as both a 15 field of representation and as a research method. Instead film is a better fit in the body of research methods that are multi-sensorial, multi-modal, practice-based and targeted towards how we experience our lived environment (Marion and Chowder 2013; Jewitt 2009; Pink 2011).

At its heart film is a form of practice-based enquiry, so it seems appropriate to adopt a practice-led approach to this article by reflecting on my own experience of using film - both as a method and one of the main publication outputs - as part of an ESRC-funded research project on heritage tourism between 2008 and 2011. 'Rebranding the Levant: contested heritage and colonial modernities in Amman and Damascus' set out to investigate the rapidly changing practices of heritage tourism in Amman and Damascus, from visiting ancient sites to living and eating in them.

In the next section I will outline the context of the project in more detail, explain its aims and objectives and why film was chosen as one of the main research methods. I will then go on to describe the collaborative methods used to film and edit the final films, with separate sections outlining the structure of each film. These are accompanied by a selection of shots from the films (Figures 1 and 2). The films I worked on were about heritage tourism; however, there is a lot to be drawn out of the process that can be applied to a wide range of research areas. In particular the way that a research film can be used to communicate and evoke emotions in the audience through a mixture of techniques such as

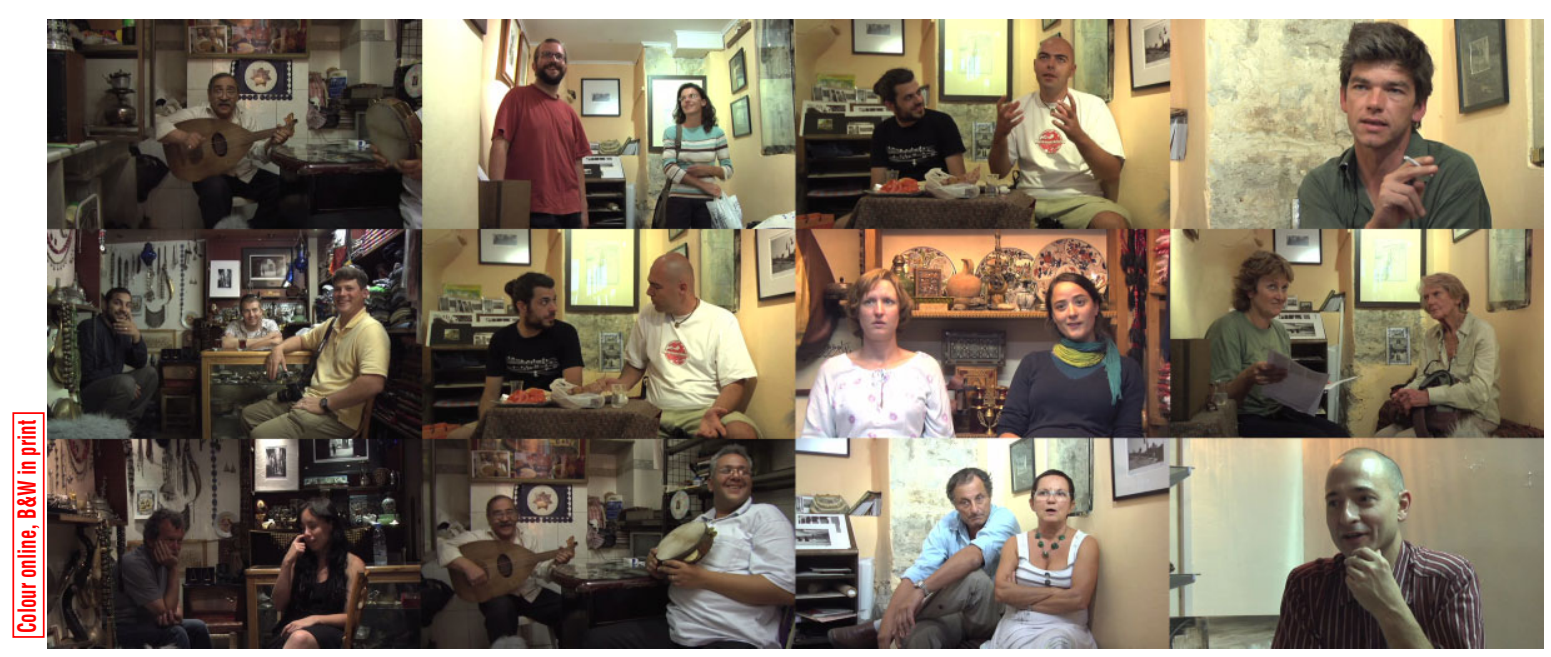

Figure 1 Music, abrupt 'soundbite' edits and humour emphasise the authorship behind the sequences Source: Jacobs (2010b) 


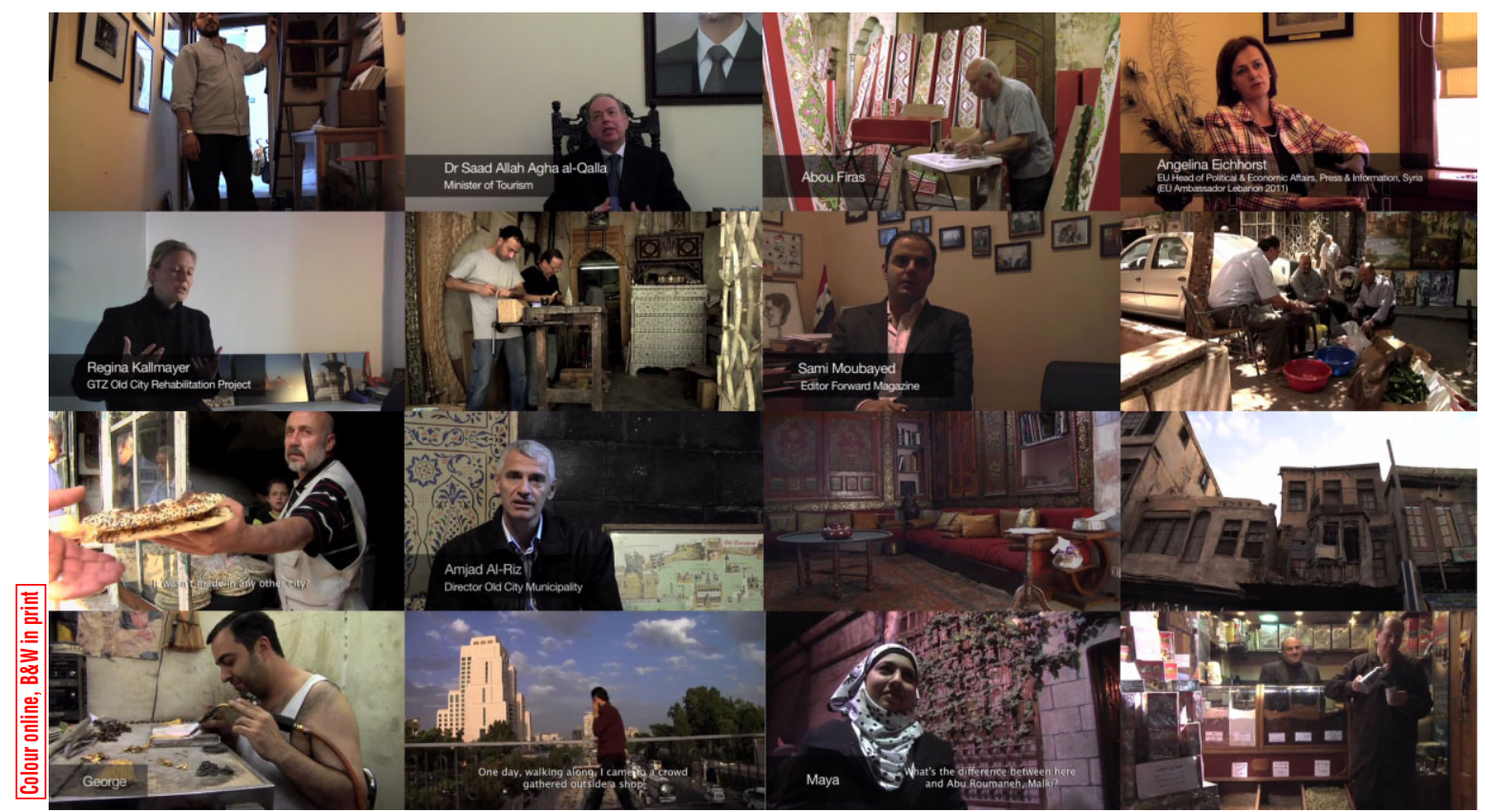

Figure 2 Match cut and sound edits are used to emphasise the contrast between different experiences of the Old City of Damascus

Source: Jacobs (2010d)

framing, camera position and the editing process. It is these attributes that make film such a compelling choice and I will conclude by offering some further points for discussion and suggesting one way that films can be better incorporated into the peer-review publication process.

\section{Visualising the past}

My research question

In 2001 at least half of the original 16832 merchant courtyard houses (bayt arabis) that were listed in the

[19] Ottoman 1900 census of Damascus in Syria (Weber 2002) were still standing, but visitors were rare and few remained after dark. But by 2006, just five years later, the Old City was deep into a process of gentrification that was transforming it into a thriving cosmopolitan space through the repurposing of many of these 'Damascene' houses into art galleries, boutique hotels, luxury fashion outlets, restaurants, cafes, bars and nightclubs.

A similar transformation was taking place in Amman, Jordan. While it lacked significant architecture from the Ottoman period, the relatively modest villas of early modernity, once occupied by colonial British administrators and other city notables, were being redeveloped into house art galleries, restaurants and cafes.

In both cities, tourists, investors, officials and locals alike were changing their embodied relationship to the material and immaterial remnants of the past. The tourist and traveller no longer had to rely on remote site visits to abandoned ruins. Now they could immerse themselves in the past physically, through an intoxicating realm of senses. They could live, sleep, bathe and eat in it.

In Syria Salamandra (2004) argued this constituted a 'local expression of a global modernity'. The past was up for grabs so that the question of what constitutes authenticity was now 'a Syrian construct' and 'a field of contestation rather than an essence' $(2004,4)$. Peleggi, commenting on the rise of 'colonial' hotels in south-east Asia, suggested the standard pattern of the heritage industry - where the use value of monuments and museums are turned into economic value through commodification was being reversed.

The monumentalisation of colonial hotels, on the contrary, transforms - or more precisely redoubles - economic value into use value at the same time that it increases marketability by 'restoration'. $(2005,264)$

Peleggi also noted how the colonial past was now being made available as 'a stage set for consumption practices and, indeed as a consumable spectacle in itself' (2005, 264). This seemed very similar to Knudsen's conclusions about the tourism to Auschwitze-Birkenau, where the 'witnessing visitor' who participates in 'scene of the crime' tourism no longer performs a gaze but 'invests 
bodily in this place and this investment becomes the coin of exchange with the past' $(2006,5)$.

\section{Fictional film vs video as fact}

As noted earlier, research into our feelings and experiences poses a challenge, not only in how we investigate them, but also in how we (re)present our findings. Smith and Anderson (2001) have noted that, aside from a few exceptions, geography has long had trouble with investigating 'subterranean' feelings. And if the landscape of emotional geography is hard to see, then it is even harder to put into words. It is this ineffable quality of emotions that puts geographers at risk of 'excluding and 'suppressing' them (Davidson et al. 2005, 2).

So can video/film offer a means to access this subterranean landscape of emotions? Film and video, though sometimes used interchangeably, also have different aesthetics and histories, use different media and devices, and are often used to refer to different final products. However, neither is purely digital because they both have analogue origins.

In academic terms, when the footage is described as a 'video' rather than a film the implication is often that fact is being collected rather than fiction being created. Video refers to an audio-visual recording of subjects that offer researchers a 'small window into lived realities that no other medium can provide' (Marion and Crowder

It shows process and captures actions and words as they naturally occur in the flow of experience. This provides us with a multidimensional way of capturing the essence of whatever we are studying. By simultaneously capturing verbal and nonverbal acts, ethnographic video provides access to multiple levels of behavioural data. ... With video you can watch a storyteller's face, see how expressions change and watch body gestures. This opens up a whole new array of analytical spaces for conducting and representing ethnographic research. $(2013,67)$

Meanwhile, film's capacity to (mis)represent and manipulate time and place via the edit or framing or adding sound carries all the connotations of a fiction. This includes the documentary film, first defined by Grierson (1932) as the 'creative treatment of actuality'. Ruby, for example, has argued that very few anthropological films are fully ethnographic because they rarely reveal their methods and are so 'concerned with satisfying the conventions of documentary film' they end up producing 'pretty pictures' (1975, 108-9). My positionality as a white European researcher looking at the people and places of the Middle East would also have a strong impact on my choice of what I represent via my camera. Ethnographic films, as Basu notes, 'have largely been films made by "us" (urban white Westerners) about "them" (our non-urban, non-white, non-Western Other)' (2008, 94).

\section{Shooting a research film}

Filming (or videoing) people and places in Amman and Damascus was fraught with the danger of reproducing cinematic stereotypes about the Arab world (Shaheen 2007) and conflating Middle Eastern heritage with a nostalgic search for a European colonial past. Both these habits have long been recognised as powerful Orientalist tools for the reinforcement of Western hegemony (Said 1978). It was therefore crucial to acknowledge and reflect 2 back on the positionality of the urban white Westerner (as both researcher and tourist).

In order to explore the power relationship of the 'them and us' dynamic, situatedness and collaboration was crucial to this project's methods as a whole, not just at the time of filming (it also became the topic of one of the final themes). I had already spent several years working in the region (as a journalist, studying Arabic and later as a Research Officer for the Council for British Research in the Levant in Amman). Without this background and network I would have struggled to find partners to collaborate with. I wanted to interview a wide range of people, including foreign tourists and residents, in order to highlight the different perspectives they had. In Damascus, I worked with a group of young Syrians who mixed with the then flourishing foreign student community, in particular Zaher Al Saghir, who ran a small art gallery in the Old City and also worked in his father's and uncle's souvenir shops. In Amman input and perspective came from Khaled Haikal, a Jordanian official working with the Ministry of Tourism and Egyptian ex-pat Dalia Salem, who had relocated to Amman to be with her French husband while he worked for the European Union. Over nine months in 2009 we visited and filmed over 100 participants (shopkeepers, tourists, heritage experts, government representatives, expatriate residents and European Union officials). The cities were also considered as participants, so framing was as wide as possible, whether it was a landscape or interview, to capture as much information about the location (and its relationship to the people on screen) as possible. By the time I returned to the UK, I had amassed over 300 hours of recorded interviews and footage of different heritage sites in both Amman and Damascus.

\section{Editing a research film and film format}

Whatever claims video might have to capture an 'essence' or 'actions and words as they naturally occur' (Marion and Crowder 2013), film is a complex form of communication, interpretation and representation. As a spectator 
'reading' a film involves a semiotics of multimodality that allows us 'to investigate the multitude of ways we communicate: though images, sound and music to gestures,

24 body posture and use of space' (Jewitt 2009). But films do not just allow us to clinically observe some of the non-visual and non-textual ways we communicate our feelings; they are a mode of representation that sets out to 'mobilise, produce and seek to shape emotions' (Davidson et al. 2005, 10). This is achieved during production, through the ways they are shot, and during editing and post-production with the addition of audio and visual effects and new meanings cutting up [25] sequences. And as Russian filmmaker Eisenstein argued, the use of music and landscape are also key to 'conveying moods, emotional states, and spiritual experiences' (1987, 217).

With Ruby's warning about 'pretty' documentaries in mind, the question now arose as to which film format would be most appropriate to (re)present the research data. Despite cinema's reliance on landscape for context and emotional affect, it is not a film format (Lefebvre 2006). Instead genres are categorised by the narrative style. Documentary 'modes' (Corner 1999; Nichols 2001) use different narrative approaches but most follow a predetermined production process in terms of development (for example storyboarding) and the final format (length and scene structure) terms. Some are produced alone (the self-shooter) but most use a professional crew constricted by time and money to no more than a few days or weeks on location.

The first sorting stage of editing had taken place while filming, when sound and video clips had been imported into editing software (Final Cut Pro) and organised into 'bins': exterior shots, close-ups, interviews, background noise etc. The decision to work with recent graduates from the National Film and Television School was at first in order to ensure the final films were of 'broadcast quality'. However, it soon became a form of collaborative peerreview, in that the editors were keen to impose the film format protocols that they had learnt at the NFTS.

Montage theory, developed in early Russian cinema, shows how the meaning of original clips, when juxtaposed next to each other in a sequence, go on to create a new meaning that was not necessarily present in the original scene. Through the power of association and (audio)visual metaphor, edited footage is able to implant 'an abstract concept into the consciousness of the spectator' through cinematic symbolism (Jacobs 1954, vii). In the context of producing a research film, the editing process can be viewed as a dialogic process resulting in the construction of a research argument as well as a wider engagement with film literacy in a more general sense.

Over several weeks working with the editors and the footage, we struggled to make a film. I had set out to ensure there was overriding narrative voice but this made a standard 56-minute film technically difficult because there would be nothing to stitch the sequences together. Moreover I was concerned that too many of the rough cuts created by the editors were too clichéd and formulaic. We were stuck. It was then that I realised the issue of length could be solved by making shorter films (from 2 to12 minutes), each covering a different theme. This also gave the video data an opportunity to have a conversation with film formats because each film could be constructed using a different editing style. Publication would be online, where they could be viewed separately or together, with or without additional text. The first film 'Rebranding the present I' (Jacobs 2010a) adopted a talking heads intercut with scenery approach, common to many documentaries on television that claim neutrality. 'Rebranding the present II' (Jacobs 2010b) referenced music videos and advertising styles by using abrupt cuts and a music soundtrack to highlight the manipulative presence of authorship. 'Rebranding the present III' (Jacobs 2010c) took a visual arts approach, separating audio from visual, incorporating still images and using a split screen, while 'Rebranding the present IV' (Jacobs 2010d) borrowed from ethnographic modes of representation, contrasting interviews with authority figures with those of local Syrians who knew Zaher Al Saghir. The use of different film style in each film was also intended as a means of revealing the research methods as well as a reminder to the audience to interrogate the mechanisms of representation when viewing. ${ }^{1}$

\section{Visualising the past, rebranding the present I}

I. Amman - The linear format. Interview footage - including medium close-up shots of authority figures in offices is intercut with shots of the urban landscape in question. 'Cutaways' are used to support or contradict verbal statements. Viewers are given the position of judge in that they feel they have been given access to all the main issues so they can come to a conclusion. This positionality encourages the viewer to identify with the expert, whose location (office) is separated from the subject (heritage). The 'authorative' perspective is somewhat destabilised by the omission of a voiceover.

Visualising the past, rebranding the present II Mysterious Syria - Brief excerpts from interviews with tourists, filmed while shopping in the Old City and responding to the same questions, are edited into in a sequence. These 'soundbites' allow individual comments to be presented as group ideas, and cutting them between a Syrian man singing and playing the oud (in a neighbouring shop) emphasises the sense of place. Landscape as background is also brought to the foreground via framing that is fixed to increase audience awareness of location. 
JOBNAME: No Job Name PAGE: 6 SESS: 10 OUTPUT: Mon Apr 13 14:10:59 2015

/Xpp84_Wiley/wiley_journal_A/AREA/area_v0_i0/area_12198

6

Visualising the visceral

Structure, and humour, is provided by the music, interaction between interviewees and timing of the cuts.

Visualising the past, rebranding the present III Audio-visual Levant - An exploration of the relationship between word, sound, image and text using still images, a split screen and a music soundtrack. The only words come from signage describing hotels, bars, cafes effectively mapping the tourist landscape. The soundtrack - a recording of a men singing at a wedding in Damascus - is taken from the same place the signs describe but recorded on a different occasion and connected via the editing process.

\section{Visualising the Past, rebranding the present IV:} bitter coffee

Bitter coffee - Highlighting the impact of film as collaboration via the 'match cut'. Sequences of formal, officebased interviews with state representatives are intercut with noisy in-situ commentaries from Zaher's friends, colleagues and neighbours in the Old City. The film cuts from the Minister of Tourism (in front of a portrait of President Assad) telling us 'tourism is an image' to a man selling bird seed to young Syrian couples who believe feeding pigeons in front of the Omayyad Mosque will help them conceive. Sound edits stray into the next scene so that banging from a metalwork shop resonates into the next scene where a retired French lighting engineer shows us his beautiful restored house in Nofara (a quarter in the Old City).

\section{Watching a research film}

When people watch films their gaze tends to move across the screen in a less restricted movement than if they are reading a book (though there is a common pattern for action shots, our gaze wanders on still shots). There have been sporadic attempts to produce a scientific language of film. In the 1960s structuralists such as Barthes (1977) and

26 Bonsiepe (1963 1965) working in semiotics attempted to identify and quantify the text-image (e.g. in an advert) as a form of rhetoric and therefore reveal the systems behind such a powerful form of 'persuasive communication' (Bonsiepe 1963). Although this idea fell out of favour, digitality has revived interest with attempts to model how audio-visual rhetoric works 'whether it be with the intention of educating the public, amusing it or arousing emotions' (Joost and Scheuermann 2008, 5).

The 'Rebranding the Levant' films were about our relationship to the past through place. As such, I took great pains to include as much of the place as possible, visually in every frame even when people were talking and through the soundtrack. Watching the films now I can see Eisenstein's argument (paraphrased by Lefebvre) that landscape and music in films are also the key methods of expressing what is 'otherwise inexpressible' and they act as 'a complex bearer of the possibilities of a plastic interpretation of emotions' (Lefebvre 2006, xi). 'Rebranding the Levant II and III' both used music to evoke a response beyond or behind the image. Ryan and Farbotko (2014) note the relationship between the 'visceral and discursive' [28] within sound, merging feminist theory 'to explore the way physical sensations connect us to 'uneven networks of power' $(2013,5)$. Nevertheless the films also carry 'aural 29 images' (Chion 1994) defined by Caquard et al. as sounds 30 that 'lack a concrete visual identity' and 'exist solely on the soundtrack in the form of music, voice-over, or pure sonic atmosphere' $(2008,1221)$. In this way the listener/ viewer can access a huge range of non-verbal aural information that interacts with the visual information.

While I purposely avoided an authorial voice-over to avoid over-direction of the audience, many people spoke to camera. For Zoller (2013) the image alone is too passive and voice is the source of agency. Adding a voice 'enters the image, breaks and dissects it; the voice deepens the meaning of the image as what we hear changes what we see'. If music and landscape are insepa- 3 rable from feelings in films, words and voice (narrative) are often considered the dominant, rational, analytical tool. Moreover the possibility arises that without voice we risk disempowering our subjects.

\section{Conclusion}

Davidson et al. have suggested that the world of emotions has been ignored in the past by geographers because emotions 'are never simply surface phenomena, they are never easy to define or demarcate, and they not easily observed or mapped' $(2005,2)$. This resonates with ToliaKelly's concern that 'embodying a "looking-onto" rather than "being with" orientation' can lead towards 'surface geographies' that 'depoliticize and make palatable the material world' (2013, 157). Aside from a rhetorical approach, improving geography's media literacy requires new skills of interpretation and analysis, particularly regarding the entangled relationship between sound (including music) and voice, and image (subject and landscape) and written words (e.g. subtitles and signage) and the way these connect to the subjects and landscapes being researched.

One of the possible reasons for our lack of attention to the emotional world might also be connected to the visual bias of language (in metaphorical English at least). When dealing with abstract (intangible) or visceral (tangible but invisible) feelings that are hard to see, they can be even harder to write about. Film's eclectic set of audio-visual techniques and technologies seem a particularly apt research tool for exploring, representing and interacting with emotional geographies. Certainly while carrying our 
research into our relationship with the past via heritage tourism, I found film could be very useful for a 'being with' rather than 'looking-onto' approach. This was evident at a number of junctures. First, the practice of using a camera is increasingly ubiquitous and already an integral part of our daily activities (especially when performing tourism). Second adopting a collaborative approach to filming not only produces different knowledges via access to a range of points of view, it also requires a serious investment of time with research participants and a willingness to go to where they live and work and cede control. Third, the technical filmmaking process that uses artificial eyes and ears to capture light then manipulates this data by focusing, framing scenes and editing sequences (manipulating time and space and the relationship between the subject and their background) can affectively offer new meanings in a media that goes beyond textual and verbal communication. Which leads us to the final juncture, watching and listening to the film. This can happen in a lecture, an online learning environment, as part of a conference presentation, in the cinema, or using a tablet, smartphone or laptop. The screening can be part of a workshop with the participants for feedback. The mutability of digitised film (Mariategui 2011), that is the way film can now be viewed on a variety of different screens and via a range of on and offline channels, allows film to circulate across a wide range of networks.

While the acts of filming collaboratively, working with editors and screening the film back to the participants, can all be likened to a form of 'peer' review that shapes and informs the final film output, the capacity to submit research films for peer-review to colleagues in the discipline is not yet established. Perhaps this is partly due to a degree of suspicion about the abilities of film to manipulate our emotions and its association with the delivery of entertainment and the marketer's art of persuasion in the film and television industry. Perhaps rather than ignoring these abilities, or attempting to limit academic films to documentary treatments of 'actuality', we should instead welcome the visceral and emotional qualities of audiovisuality and use it to advantage, as an opportunity to work with the ineffable. Using video as a research method that then becomes your final research output as a film puts a research film in a very interesting place. A research film should not have to mimic the peer-reviewed journal article in its current form, or be presented uncritically as a 'documentary', 'ethnography' or 'videography' without any analysis of the choice of media of representation. Peer review is nevertheless crucial but models already exist in practice-based disciplines like Drama, where performances are submitted with an abstract for review. Geography journals could allow research films to be submitted (with an accompanying template outlining the film's research questions, context, methods and objectives) for review and the review is then published. This will make films eligible to be assessed for quality of research by systems such as the UK's Research Excellence Framework.

\section{Note}

1 While the video that was recorded was manipulated to present a narrative and landscape, no additional material (audio or visual) was used that did not originate from the site of fieldwork.

\section{References}

Barthes R 1977 Image, music, text Hill and Wang, New York Basu P 2008 Reframing ethnographic film in Austin T and de Jong W eds Rethinking documentary: new perspectives and practices Open University Press McGraw-Hill, Maidenhead 94-106

Bliss E 2009 Placing emotions through digital storytelling: exploring new methods in geography Te Kura Kete Aronui Graduate and Postgraduate E-Journal 4

Bonsiepe G 1961 Persuasive communication: towards a visual rhetoric in Crosby T ed Upper Case 5 19-34

Bonsiepe G 1965 Visual/verbal rhetoric UIM 14/15/16 23-40

Caquard S, Brauen G, Wright B and Jasen P 2008 Designing sound in cybercartography: from structured cinematic narratives to unpredictable sound/image interactions International Journal of Geographical Information Science 22 1219-45

Castree N 2014 The Anthropocene and Geography I: the back story Geography Compass 8 436-49

Chion M 1990 Audio-vision sound on screen Columbia University Press, New York

Corner J 1999 Critical ideas in television studies Clarendon Press, Oxford

Cosgrove D and Daniels S eds 1988 The iconography of landscape: essays on the symbolic representation, design and use of past environments Cambridge Studies in Historical Geography Cambridge University Press, Cambridge

Cresswell T and Dixon D eds 2002 Engaging film: geographies of mobility and identity Rowman \& Littlefield, Lanham MD

Daher R 2007 Reconceptualising tourism in the Middle East: place, heritage, mobility and competitiveness in Daher $\mathbf{R}$ ed Tourism in the Middle East: continuity, change and transformation Channel View, Clevedon 1-69

Davidson J, Bondi L and Smith M 2005 Emotional geographies Ashgate, Aldershot

Gandy M 2007 Mumbai: liquid city UCL Urban Laboratory 28 mins (http://www.youtube.com/watch?v=u2UPPjlgb9k) Accessed 15 March 2015

Garrett B L 2011 Videographic geographies: using digital video for geographic research Progress in Human Geography 35 $521-41$

Grierson J 1932 The first principles of documentary Cinema Quarterly (1) in Grierson J and Hardy F eds 1966 Grierson on documentary University of California Press, Berkeley CA

Jacobs J 2010a Visualising the past; rebranding the present I 10.02 (https://vimeo.com/20599046) Accessed 21 March 2015 
JOBNAME: No Job Name PAGE: 8 SESS: 10 OUTPUT: Mon Apr 13 14:10:59 2015

/Xpp84_Wiley/wiley_journal_A/AREA/area_v0_i0/area_12198

Visualising the visceral

Jacobs J 2010b Visualising the past; rebranding the present II 9.04 (https://vimeo.com/20321329) Accessed 21 March 2015

Jacobs J 2010c Visualising the past; rebranding the present III 2.21 (https://vimeo.com/20323519) Accessed 21 March 2015

Jacobs J 2010d Visualising the past; rebranding the present IV 12.38 (https://vimeo.com/19823066) Accessed 21 March 2015

Jacobs L 1954 Introduction in Pudovkin V I Film technique and film acting: the cinema writings of V. I. Pudovkin Trans Ivor Nontagu Vision, Ormskirk

Joost G and Scheuermann A 2006 Audiovisual rhetoric: a metatheoretical approach to design in Proceedings Design Research Society International Conference Lisbon (http:// www.iade.pt/drs2006/wonderground/proceedings/fullpapers/ DRS2006_0031.pdf) Accessed 12 March 2015

Joost G, Buchmüller S and Englert R 2009 Audio-visual rhetoric: visualizing the pattern language of film in Undisciplined! Design Research Society Conference Sheffield Hallam University, Sheffield (http://shura.shu.ac.uk/556/) Accessed 12 March 2015

Kindon S, Pain R and Kesby M eds 2007 Participatory action research approaches and methods: connecting people, participation and place Routledge, London

Knudsen B T 2006 Emotional geography: authenticity, embodiment and cultural heritage Ethnologia Europaea: Journal of European Ethnology 36 5-15

Laurier E, Strebel I and Brown B 2008 Video analysis: lessons from professional video editing practice Forum: Qualitative Social Research 937

38 Lean D dir 1962 Lawrence of Arabia Film

Lefebvre H 2006 Landscape and film Routledge, New York

Lukinbeal C and Zimmermann S 2006 Film geography: a new subfield Erdkunde Band 60 315-25

Mariátegui J 2011 Deconstructing digital video: the ontological and technical complexities of a medium in Reassembling Organizations 27th EGOS Colloquium, Gothenburg, Sweden (https://www.academia.edu/1190486/Deconstructing_Digital _Video_The_Ontological_and_Technical_Complexities_of_a _Medium) Accessed 12 March 2015

Massey D 2011 Landscape/space/politics: an essay Atlas: Geography, Architecture and Change in an Interdependent World Black Dog, London (http://thefutureoflandscape.wordpress .com/landscapespacepolitics-an-essay/) Accessed 12 March 2015
Merchant S 2011 The body and the senses: visual methods, videography and the submarine sensorium Body \& Society 17 53-72

Nichols B 2001 Introduction to documentary Indiana University Press, Bloomington IN

Parr H 2007 Collaborative film-making as process, method and text in mental health research Cultural Geographies 14 114-38

Peleggi M 2005 Consuming colonial nostalgia: the monumentalisation of historic hotels in urban South-East Asia Asia Pacific Viewpoint 46 255-65

Pink S 2012 Advances in visual methodology Sage, London

Rose G 2003 On the need to ask how, exactly is Geography visual? Antipode 35 212-21

Rose G 2006 Visual methodologies: an introduction to the interpretation of visual methods 2 nd edn Sage, London

Ruby J 1975 Is an ethnographic film a filmic ethnography? Studies in the Anthropology of Visual Communication 2 104-11

Shaheen J 2007 Reel bad Arabs: how Hollywood vilifies a people Olive Branch Press, Ithaca NY

Said E 1977 Orientalism Routledge \& Kegan Paul, London

Salamandra C 2004 A new Old Damascus: authenticity and distinction in urban Syria Indiana University Press, Bloomington IN

Smith S J 1997 Beyond Geography's visible worlds: a cultural politics of music Progress in Human Geography 21 502-29

Smith S J and Anderson K 2001 Editorial: Emotional geographies Transactions 26 7-10

Tolia-Kelly D P 2013 The geographies of cultural geography III: material geographies, vibrant matters and risking surface geographies Progress in Human Geography 37 153-60

Waitt G, Ryan E and Farbotko C 2014 A visceral politics of sound Antipode 46 283-300

Weber S 2007 Damascus 1900: urban transformation, architectural innovation and cultural change in a late Ottoman City (1808-1918) in Proceedings of the Danish Institute Damascus Aarhus University Press, Aarhus

Zoller M 2013 Voicing agency: towards a (mis)understanding of Renzo Martens' Episode 3: Enjoy Poverty ARTTERRITORIES (http://www.artterritories.net/?page_id=3031) Accessed 12 March 2015 


\section{AUTHOR QUERY FORM}

Dear Author,

During the preparation of your manuscript for publication, the questions listed below have arisen. Please attend to these matters and return this form with your proof.

Many thanks for your assistance.

\begin{tabular}{|c|c|c|}
\hline $\begin{array}{l}\text { Query } \\
\text { References }\end{array}$ & Query & Remarks \\
\hline 1 & $\begin{array}{l}\text { AUTHOR: Please confirm that given names (red) and surnames/family } \\
\text { names (green) have been identified correctly. }\end{array}$ & \\
\hline 2 & $\begin{array}{l}\text { AUTHOR: References cannot be cited in the Abstract (journal style), so } \\
\text { I've adapted the abstract text accordingly. }\end{array}$ & \\
\hline 3 & $\begin{array}{l}\text { *AUTHOR: To match the reference list, should Cosgrove and Daniel's } \\
1988 \text { be changed to Cosgrove and Daniels, } 1988 \text { ? Please advise }\end{array}$ & \\
\hline 4 & $\begin{array}{l}\text { AUTHOR: Cited in the text, publication details needed for References: } \\
\text { Haw and Hadfield } 2011\end{array}$ & \\
\hline 5 & $\begin{array}{l}\text { AUTHOR: Cited in the text, publication details needed for References: } \\
\text { Pauwels } 2010\end{array}$ & \\
\hline 6 & $\begin{array}{l}\text { AUTHOR: Cited in the text, publication details needed for References: } \\
\text { Rose } 2001\end{array}$ & \\
\hline 7 & $\begin{array}{l}\text { AUTHOR: Cited in the text, publication details needed for References: } \\
\text { Lukinbeal } 2014\end{array}$ & \\
\hline 8 & $\begin{array}{l}\text { AUTHOR: Please give the source for this quote: This means that } \\
\text { 'underlying literacies that link geography to media remain uncharted' }\end{array}$ & \\
\hline 9 & $\begin{array}{l}\text { AUTHOR: Cited in the text, publication details needed for References: } \\
\text { Kieller } 2010\end{array}$ & \\
\hline 10 & $\begin{array}{l}\text { AUTHOR: Cited in the text, publication details needed for References: } \\
\text { Collard } 2014\end{array}$ & \\
\hline 11 & $\begin{array}{l}\text { AUTHOR: Cited in the text, publication details needed for References: } \\
\text { Laurier } 2010\end{array}$ & \\
\hline 12 & $\begin{array}{l}\text { AUTHOR: Cited in the text, publication details needed for References: } \\
\text { Baptiste } 2014\end{array}$ & \\
\hline 13 & $\begin{array}{l}\text { AUTHOR: Cited in the text, publication details needed for References: } \\
\text { Bliss } 2011 \text { (or should this be Bliss } 2009 \text { as in References but not cited in } \\
\text { the text) }\end{array}$ & \\
\hline 14 & $\begin{array}{l}\text { AUTHOR: Cited in the text, publication details needed for References: } \\
\text { Rose } 2012\end{array}$ & \\
\hline 15 & $\begin{array}{l}\text { *AUTHOR: To match the reference list, should Mariategui, } 2011 \text { be } \\
\text { changed to Mariátegui, 2011? Please advise }\end{array}$ & \\
\hline
\end{tabular}


JOBNAME: No Job Name PAGE: 10 SESS: 10 OUTPUT: Mon Apr 13 14:10:59 2015

/Xpp84_Wiley/wiley_journal_A/AREA/area_v0_i0/area_12198

\begin{tabular}{|c|c|c|}
\hline $\begin{array}{l}\text { Query } \\
\text { References }\end{array}$ & Query & Remarks \\
\hline 16 & $\begin{array}{l}\text { AUTHOR: Cited in the text, publication details needed for References: } \\
\text { Marion and Chowder } 2013\end{array}$ & \\
\hline 17 & $\begin{array}{l}\text { AUTHOR: Cited in the text, publication details needed for References: } \\
\text { Jewitt } 2009\end{array}$ & \\
\hline 18 & $\begin{array}{l}\text { AUTHOR: Cited in the text, publication details needed for References: } \\
\text { Pink } 2011 \text { (or should this be Pink } 2012 \text { as in References but not cited in } \\
\text { the text) }\end{array}$ & \\
\hline 19 & $\begin{array}{l}\text { AUTHOR: Cited in the text, publication details needed for References: } \\
\text { Weber } 2002 \text { (or should this be Weber } 2007 \text { as in References but not } \\
\text { cited in the text) }\end{array}$ & \\
\hline 20 & $\begin{array}{l}\text { AUTHOR: Cited in the text, publication details needed for References: } \\
\text { Marion and Crowder } 2013\end{array}$ & \\
\hline 21 & $\begin{array}{l}\text { AUTHOR: Please give the page no. of these original quotes: Please give } \\
\text { the page no. of these original quotes: offer researchers a 'small window } \\
\text { into lived realities that no other medium can provide' (Marion and } \\
\text { Crowder 2013). }\end{array}$ & \\
\hline 22 & $\begin{array}{l}\text { AUTHOR: Cited in the text, publication details needed for References: } \\
\text { Said } 1978 \text { (or should this be Said } 1978 \text { as in References but not cited in } \\
\text { the text) }\end{array}$ & \\
\hline 23 & $\begin{array}{l}\text { AUTHOR: Please give the page no. of these original quotes: capture an } \\
\text { 'essence' or 'actions and words as they naturally occur' (Marion and } \\
\text { Crowder 2013), }\end{array}$ & \\
\hline 24 & $\begin{array}{l}\text { AUTHOR: Please give the page no. of these original quotes: film is a } \\
\text { complex form of communication, interpretation and representation. As a } \\
\text { spectator 'reading' a film involves a semiotics of multimodality that } \\
\text { allows us 'to investigate the multitude of ways we communicate: though } \\
\text { images, sound and music to gestures, body posture and use of space' } \\
\text { (Jewitt 2009). }\end{array}$ & \\
\hline 25 & $\begin{array}{l}\text { AUTHOR: Cited in the text, publication details needed for References: } \\
\text { Eisenstein } 1987\end{array}$ & \\
\hline 26 & $\begin{array}{l}\text { AUTHOR: Cited in the text, publication details needed for References: } \\
\text { Bonsiepe } 1963\end{array}$ & \\
\hline 27 & $\begin{array}{l}\text { AUTHOR: Cited in the text, publication details needed for References: } \\
\text { Joost and Scheuermann } 2008 \text { (or should this be Joost and Scheuermann } \\
2006 \text { as in References but not cited in the text) }\end{array}$ & \\
\hline 28 & $\begin{array}{l}\text { AUTHOR: Cited in the text, publication details needed for References: } \\
\text { Ryan and Farbotko (2014) and (2013) }\end{array}$ & \\
\hline
\end{tabular}


JOBNAME: No Job Name PAGE: 11 SESS: 10 OUTPUT: Mon Apr 13 14:10:59 2015

/Xpp84_Wiley/wiley_journal_A/AREA/area_v0_i0/area_12198

\begin{tabular}{|c|c|c|}
\hline $\begin{array}{l}\text { Query } \\
\text { References }\end{array}$ & Query & Remarks \\
\hline 29 & $\begin{array}{l}\text { AUTHOR: Please check - two different dates for same author? Ryan } \\
\text { and Farbotko (2014) note the relationship between the 'visceral and } \\
\text { discursive' within sound, merging feminist theory 'to explore the way } \\
\text { physical sensations connect us to 'uneven networks of power' }(2013,5) \text {. }\end{array}$ & \\
\hline 30 & $\begin{array}{l}\text { AUTHOR: Cited in the text, publication details needed for References: } \\
\text { Chion } 1994 \text { (or should this be Chion } 1990 \text { as in References but not } \\
\text { cited in the text) }\end{array}$ & \\
\hline 31 & $\begin{array}{l}\text { AUTHOR: Please give the page no. of these original quotes: For Zoller } \\
(2013) \text { the image alone is too passive and voice is the source of agency. } \\
\text { Adding a voice 'enters the image, breaks and dissects it; the voice } \\
\text { deepens the meaning of the image as what we hear changes what we see' }\end{array}$ & \\
\hline 32 & $\begin{array}{l}\text { AUTHOR: Would you like to include an Acknowledgements section, to } \\
\text { mention the referees of your paper and any funding? }\end{array}$ & \\
\hline 33 & $\begin{array}{l}\text { AUTHOR: Listed in the References, please cite in the text: Bonsiepe } \\
1961\end{array}$ & \\
\hline 34 & $\begin{array}{l}\text { AUTHOR: Listed in the References, please cite in the text: Castree } \\
2014\end{array}$ & \\
\hline 35 & AUTHOR: Listed in the References, please cite in the text: Daher 2007 & \\
\hline 36 & $\begin{array}{l}\text { AUTHOR: Listed in the References, please cite in the text: Joost et al. } \\
2009\end{array}$ & \\
\hline 37 & $\begin{array}{l}\text { AUTHOR: Listed in the References, please cite in the text: Laurier et al. } \\
2008\end{array}$ & \\
\hline 38 & AUTHOR: Listed in the References, please cite in the text: Lean 1962 & \\
\hline 39 & AUTHOR: Listed in the References, please cite in the text: Rose 2003 & \\
\hline 40 & AUTHOR: Listed in the References, please cite in the text: Rose 2006 & \\
\hline 41 & AUTHOR: Listed in the References, please cite in the text: Smith 1997 & \\
\hline 42 & $\begin{array}{l}\text { AUTHOR: Listed in the References, please cite in the text: Waitt et al. } \\
2014\end{array}$ & \\
\hline
\end{tabular}

Note: The query which is preceded by $*$ is added by Toppan Best-set. 


\section{Author Services}

Wiley-Blackwell Author Services can be accessed by visiting

http://authorservices.wiley.com/bauthor/ or by following the link from your email.

Wiley-Blackwell Author Services allows you to track the production status of your accepted articles, add co-authors and distribute your articles to your colleagues.

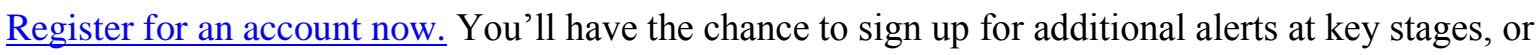
you may just log in from time to time to check on your article's status.

Please note that you must have received an e-mail from a journal with your article ID in order to track the production status of your article. The format of the Unique ID is 123456-123456. Unfortunately the ScholarOne Manuscripts tracking number is separate and will not work in Author Services.

If you wish to submit a manuscript to the editorial office for review, please use the "Guidelines by Journal" at the right to find the specific journal.

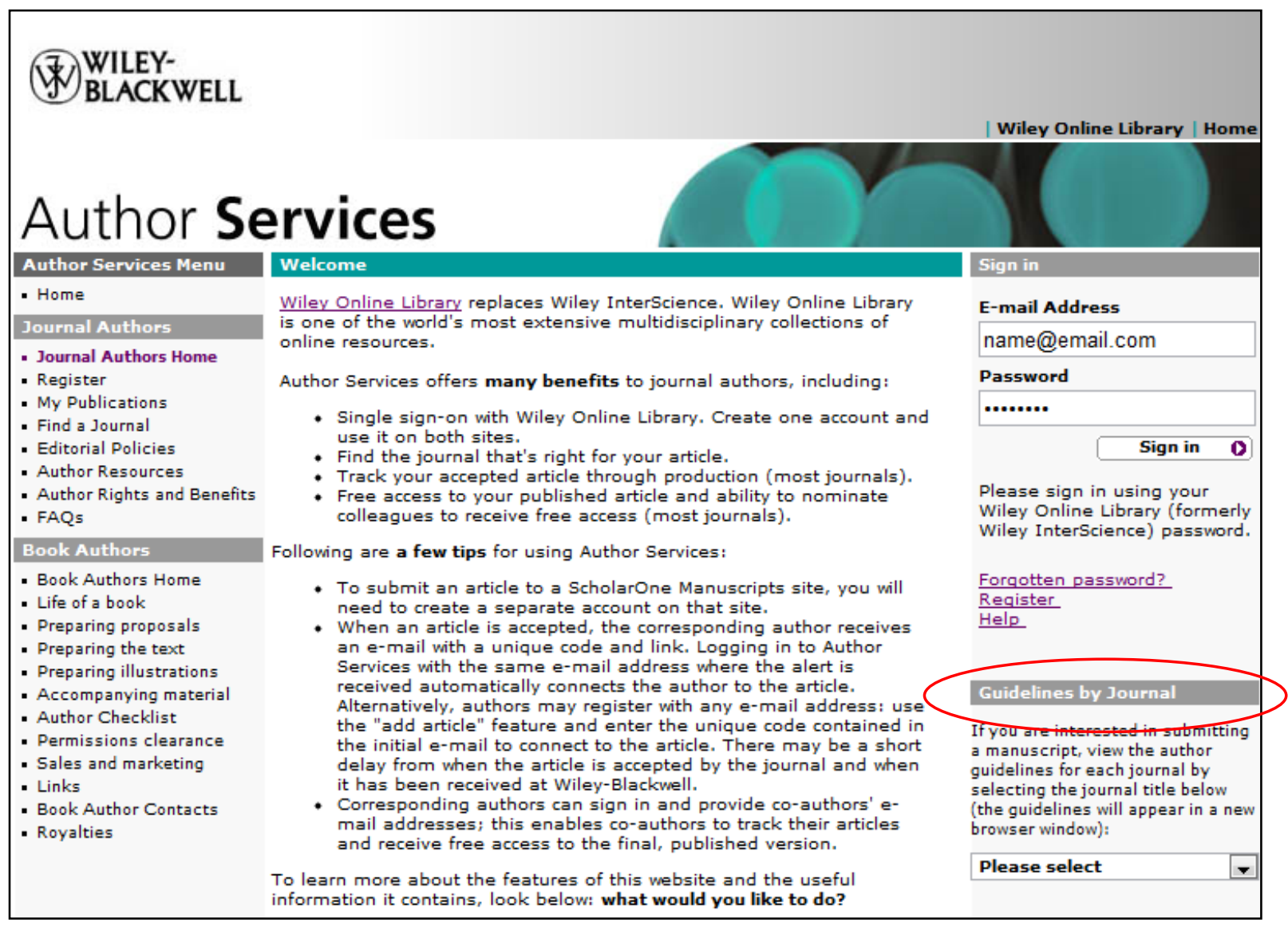

The instructions contain the link to the manuscript submission website if applicable, which is separate from Author Services. If the journal does not offer online submission, the instructions will contain the address to which you should send your manuscript

Once you have received an article ID, you can add an article to your profile:

1. If you have previously registered in Author Services, click on the link in the e-mail and log in. If your login (e-mail address) matches the address where the initial alert was sent, then you will be connected automatically to your article. 
2. If you have never registered, click on the link in the e-mail and register. If your username (email address) matches the address where the initial alert was sent, you'll be connected automatically to your article.

3. If you wish to register at an e-mail address other than the one to which the alert was sent, you can add the article to your profile by following the instructions below.

\section{Add an article}

To add an accepted article to your My Publications profile, click on the 'Add a new article' button and enter the Unique ID for your article. This is included in your initial email alert and the format is 123456-123456. If you have forgotten or mislaid your article code, please contact e-help.

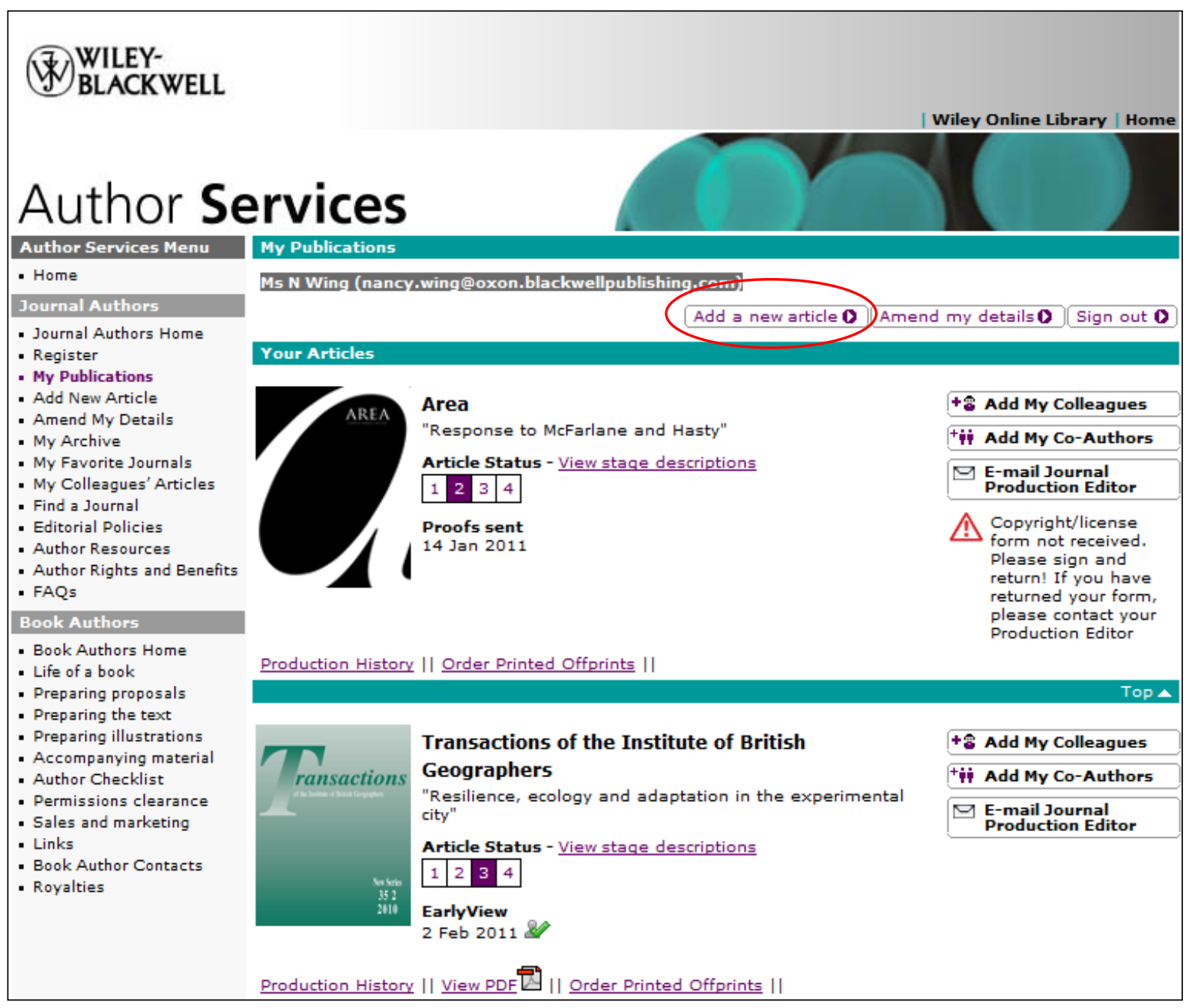

Once you have added your article, you can track its current article status, view its production history, and order printed offprints.

The four stages you are able to track your article through are:

- Accepted article received

- Proofs sent

- Corrections received

- Issue published online 
If your article is published as Early View online prior to appearing in an issue, a further notification will appear below the Article Status tracker and a 'View PDF' link will be added to allow you to view your article.

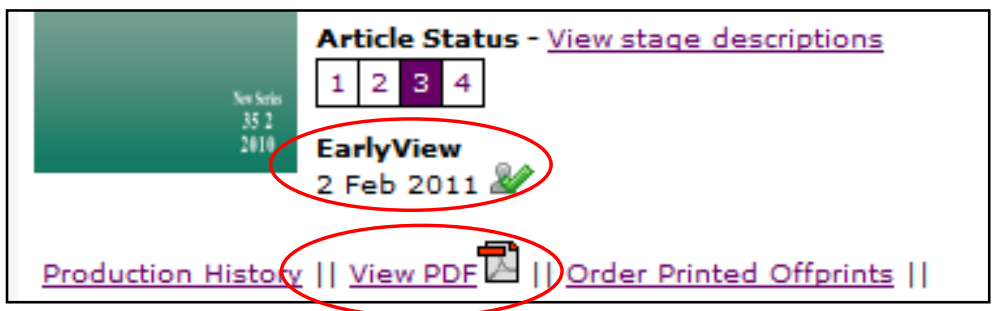

\section{Add My Colleagues}

Enter the e-mail addresses of up to 10 colleagues to disseminate your paper to key readers. An invitation to register in Author Services will be sent to each colleague to invite him or her to view your article once it has been published online. If your colleague has already registered in Author Services, the e-mail will contain instructions on how to add

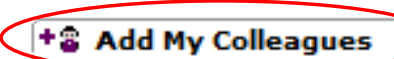

+ i Add My Co-Authors

E-mail Journal Production Edito the article to his or her account. The e-mail address will not be used for anything other than an invitation to register in Author Services. This feature is designed to support article usage as well as citations. Online usage is becoming increasingly important, so we encourage you to take advantage of this way of promoting your article.

\section{Add My Co-Authors}

Enter the e-mail addresses of your co-author(s). An invitation to register in Author Services will be sent to each co-author so he or she can track production and view the article online using separate log-in details from yours. If your co-author has already registered in Author Services, the e-mail will contain instructions on how to add the article to his or her account. The e-mail address will not be used for anything other than an invitation to register in Author Services.

\section{E-mail Journal Production Editor}

If you have any concerns over the progress of your article, you can use this button to contact the production editor directly.

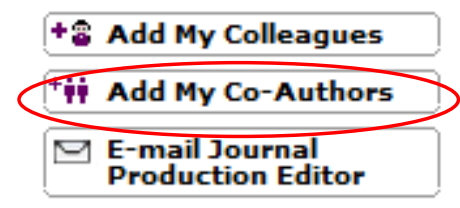

